\title{
COVID-19 and the Linear Perspective of Global Security
}

\author{
Awaisu Imurana Braimah \\ Faculty of Social Sciences Education, University of Education, Winneba, Ghana
}

\section{Email address:}

baimurana@uew.edu.gh, braawaisu@yahoo.com

\section{To cite this article:}

Awaisu Imurana Braimah. COVID-19 and the Linear Perspective of Global Security. International and Public Affairs. Vol. 4, No. 2, 2020, pp. 63-70. doi: 10.11648/j.ipa.20200402.16

Received: August 22, 2020; Accepted: September 11, 2020; Published: September 19, 2020

\begin{abstract}
This paper diagnoses the interaction and behaviour of states in the international system in the light of the blush of global pandemic and potential security threat. Globally, humankind continue to witness slough diseases such as Severe Acute Respiratory Syndrome (SARS), Middle East Respiratory Syndrome (MERS), Ebola, Human Immune Virus/Acquire Immune Deficiency Syndrome (HIV/AIDS), H5N1 (avian/Bird flu), Swine fever, Malaria and in recent times, coronavirus (COVID-19) which has been declared by the World Health Organization (W.H.O) as Public Health Emergency of International Concern (PHEIC). Since the outbreak of the COVID-19 pandemic, states with financial wherewithal or capacity have hastily dispatched airplanes and ships to evacuate compatriots from afflicted states as both protective and preventive mechanisms. Since the COVID-19 virus spread to other parts of the world, it is axiomatic that the evacuation mechanism could serve as a conduit for the 'importation' of the virus from affected countries to the countries purporting to be providing safe haven for the evacuees. Undoubtedly, the evacuations increased the geopolitical spread of viruses or microbes around the world. The study argues that states need to join forces scientifically and financially to nib the spread of infectious diseases in the bud by dealing with the menace in the country of origin as a preventive measure to eliminate or minimize spread of viruses or diseases.
\end{abstract}

Keywords: Coronavirus, Global Heath, Global Security, Infectious Disease, Public Health

\section{Introduction}

Severe Acute Respiratory Syndrome-COV2 (or SARSCOV-2) is the real name of the current pandemic popularly refers to as Coronavirus or COVID-19. "Corona" is derived from Latin root which means, ring of light [1]. It refers to the configuration of the virus when observed under a microscope Just as it is with HIV/AIDS, SARS, Ebola and MERS, COVID-19 is pathogenic, and spread like wildfire from person to person and in some rare situations, can be transmitted from animals to humans. The devastating effects of pandemics are well documented in terms of human life, fear and panic, national and global security concerns, economic recession, unemployment, poverty and restriction on human movements among others. According to Huang,

...globalization and the growing economic interdependence means that even countries with few or no cases of a disease have to deal with the economic shocks caused by the spread of infections within a region [2].

The novel COVID-19 pandemic was first reported in Wuhan (Hubei province), China - specifically in December,
2019. It is still a moot point whether COVID-19, was an artificial creation or conspiracy of one state (biological attack) and targeted at a particular state or states, or it was purely a natural cause. This paper does not seek to contribute to such raging debate. Rather, it seeks to diagnose the behaviour of states in the international system in the wake of the pandemic.

Health and security issues are top-notch critical studies in the field of International Relations (IR) in contemporary times. For, in the words of Mclnnes \& Lee,

....infectious diseases have never recognized state boundaries and systems of international cooperation attempting to control their spreada... [3].

States are unitary actors in the international system. Hence, individual states show much concern about issues of realpolitik and the promotion of its national interest vis-à-vis other states. As a result, the behaviour of states during a pandemic of global proportion (e.g., COVID-19 my focus) is to customarily, safeguard the interest of their citizens through evacuations from the foreign land. Evacuations have not been entirely useful. They have proven to be useful in situations of potential outbreak of lethal conflict or xenophobic attacks from a host nation. For instance, Western and European states 
normally issue travel warnings to their citizens to leave potential areas in the international system where their security cannot be guaranteed. In many situations, states with financial wherewithal, normally dispatch airplanes and/or ships for evacuation mission of their citizens as happened during the Arab spring in the Middle East and North Africa. States with weak economies 'sacrifice' their citizens. They only call on the host nation to give adequate security to their compatriots according to established international law and conventions. Whereas the evacuations are useful in conflict situations, they are not useful in disease-related phenomena. In fact, evacuation of citizens to escape an infectious disease of global concern in a foreign land is costly in two main ways First, states are always in panic mood to safeguard their citizens from the epicentre of an infectious disease sometimes due to domestic pressure - end up evacuating already infected citizens with speed demon into the state. This has proven to be insalubrious and detrimental to the health of the multitude of citizens residing in a state who may not have acquired or possess a passport or travel abroad with catastrophic and needless deaths. The United States of America and other European states that embarked on evacuation mission in China, are now suffering from the coronavirus as their well-intended evacuations have turned out to be the means through which the USA, France, Germany, Italy, Britain, Russia among others, imported the virus and/or aided the spread of the virus in their jurisdiction. Second, the draconian policies (such as lockdown of cities, shops, sporting activities, aviation etc) adopted by many European states to control COVID-19 have had debilitating effects on the local economy (e.g. toll on businesses, unemployment, stark poverty, leading to a distortion of market equilibrium and anomalies in the operations of price mechanism for goods and services) with concomitant threat to national security. It is therefore inappropriate for global actors and statesmen to seek to tackle a global pandemic of global concern like coronavirus through the resort to evacuation as the first option. Instead, as a first step, it is appropriate for the international community to team up with Health Professionals around the globe to nib the disease in the bud at the epicentre as a key way to deal with the pandemic effectually and efficiently.

Infectious disease of whatever kind, is a threat to national and global security. Infectious diseases pose significant threat of extinction to national populations, human resource, productivity and states stability. In this study, coronavirus is constructed as both national and global security threat, a conundrum with withering character on humanity, security, politics, governance and the global economy. Historically, pandemic diseases have been lethal and devastating to human lives than conventional wars. For instance, in the $14^{\text {th }}$ Century, the Black Death (the Bubonic Plague) killed between 25 and 50 per cent of European population of about 75 million between 1347 and 1351 ([4], p, 298). In fact, "of the total English population of perhaps 4.2 million, probably 1.4 million died of the Black Death" in England in $14^{\text {th }}$ century ([5] p. 440). In another scenario, in World War I, an estimated number of 20 million military and civilian death toll was recorded. The 1918 outbreak of Spanish flu killed as many as 50 million people [6]. The staggering death toll was trailed by economic, political, social and security consequences that continue to haunt the world for well over a century [7]. The didactics of global pandemics demand a multifaceted approach by states to confront head-on, the threat of extinction of humans and its concomitant security threats to national and global political economy. The thrust of this paper is to track and examine the behaviour of states since the outbreak of COVID-19, its effects on global security, governance, economy, and, to proffer future policy actions for states to ponder.

Methodologically, the data for this study is of two-fold schema. The first set of information was gathered from various international and local media reportage on the coronavirus pandemic as well as World Health Organization (W.H.O) and Ghana Health Service (G.H.S) websites. Researcher's observation of the perfunctory behaviour and attitude of Western and European states since the outbreak of the pandemic. Secondary literature such as monographs, reports, and journal articles on infectious diseases of public health were utilized. These pieces of information were incorporated into the study and scrutinized for analytical purposes

\section{Realists on States Behaviour}

There is a plethora of theories that succinctly explains behaviour of states in the international system. In this study, the Realist paradigm is employed to explain behaviour of states in the wake of the emergence and spread of COVID-19 pandemic that has so far wreaked havoc on all facets of humanity. Since the dawn of history, humankind have continuously grapple with unknown infectious diseases of public health concern. These new pathogenic disease emerge (e.g. coronavirus pandemic understudy) with no known effective and immediate prophylactic to halt its destructive character on humans. Neither would there be existing robust measures to pre-empt the pandemic from disruptions in the functioning of the global economy. While it may be difficult for scientists across the globe to develop vaccines against an abstract or unknown futuristic pandemic, the collective coordination of states and scientific knowledge on infectious diseases around the world may reduce collateral damage on each state. However, whenever there is a pandemic, states 'selfishly' and unrepentantly work for their interest, vis-à-vis other states in the international system. In other words, instead of pooling human and material resources to combat infectious diseases of public health concern, states around the world are normally adamant and perceives the disease as belonging only to the epicentre. This standpoint facilitates the spread of diseases (e.g., SARS, Spanish flu, Ebola, Avian flu etc) to other parts of the world.

Realism is a School of Thought that perceives power as the main element in the conduct of international relations - be it military, political, legal, social, and in contemporary times, 
economic and cultural relations between and among states. Realists assume that the absence of a sovereign authority or world government to make and enforce binding agreements creates opportunities for states to advance their interests unilaterally and makes it important and difficult for states to cooperate with one another [8]. States clothed with 'global power' also have the capacity to cajole other states to formulate foreign policy decisions desired by the 'powerful' state so called. In the realists view, there is no cooperation in the international system since we live in a grim world. Hence, states in the international system resort to unforesightful policy of 'my country first kind-of' approaches in their dealings with other states. In the event of an outbreak of a pandemic, communal violence or international war, states customarily, resort to 'protectionists' and 'isolationists' policies. 'Self-help', instead of global cooperation becomes the hallmark for state's preservation and foreign policy. In the international system, states are obliged to look after themselves, because there is no one else to look after them. States desire to preserve themselves in terms of security and power and perceives any other state as a potential threat [9, $10]$.

Relating realism to current pandemic (i.e. coronavirus), states at the onset of the virus, considered the virus as a 'Chinese problem'. Political leadership across the world, watched the Chinese government from afar struggling to curb the spread of the virus from Wuhan to other parts of China states are normally aloof or distant when an issue of global concern did not immediately pose direct security threat. This was the case since the emergence of COVID-19 pandemic that was officially reported to have begun in November, 2019 The Western world and many other European states could have dispatched health professionals from their respective countries as was the case of Ebola in West Africa, to assist the Chinese government to root out or halt the spread of the virus. On the contrary, states pursued 'self-help', 'selfinterests' and 'protectionist policies' through evacuation of nationals from China as well as shattering of borders as a quid pro qou of preventing the virus import. In the end, the disease spread and engulfed the rest of the world with impunity. Self-centredness and miscalculation of leaders around the world - the virus seen to be thousands of kilometres away from home country - is rooted in realist thought. This short-sightedness further exacerbates the unbridled spread of the virus with its debilitating effects on the global economy. Cooperation of states that could have culminated in a united and coordinated response to suppress the spread of the pandemic is still lacking or inadequate. Hence, the smouldering of the pandemic around the world seems to go unabated. There is no doubt that COVID-19 is a global pandemic that need a global response. In 2004, the World Health Organization and the Food and Agriculture Organization jointly admonished states to cooperate in their quest to root out pandemics. WHO-FAO declared:

With SARS, we learned that only by working together can we control emerging public health threats. Now, we confront another threat to human health (Avian Influenza) and we must reaffirm existing collaboration and form new one ... [11].

However, developed and developing states moved by greed, self-interest and instrumentalism, have devised individual slipping and slithering policies in an attempt to halt the negative impact of COVID-19 with little progress. Governments, driven by fear about the threat of a pandemic, crave to stockpile anti-viral medications and vaccines (as it was during the outbreak of H5N1) for security purposes [12]. In the process, several deficiencies including considerable misinformation and disinformation circulating among member states, has limited the world's ability to efficiently and effectively respond to the withering crisis of COVID-19 pandemic [13]. States are already ingrained in selfish vaccine nationalism and geopolitical influence even though a fullyfledged vaccine is yet to come into fruition. Wealthy states will likely determine the distribution of COVID-19 vaccine with inward-looking approaches instead of working together globally to preserve human life.

\section{Spread of COVID-19}

The spread of COVID-19 or SARS-2 and the behaviour of the virus have attracted scientific studies, results of which have been well-documented to be recounted here. Suffice it, however, to say that the unprecedented spread of COVID-19 pandemic and its pandemonium around the globe is linked to many factors such as the interconnectedness of the world and people (globalization), prevarication of states about the disease, initial perception of the disease as 'Chinese-virus' by global actors, the precipitous or headlong haste evacuation of nationals from the epicentre, delayed testing and contact tracing, dysfunctional and disarticulation of health care systems of states, and poor investments in developed and developing countries in the health sector.

First, the spread of COVID-19 across the globe lend credence to the interconnectedness of states and people globalization. The world is inextricably intertwined and integrated to the extent that, whatever happens in one part of the world, affects every other area of the world. While there is sufficient literature and evidence pointing to the interconnectedness and interdependence of states and people, there has not been enough complementarity in healthcare investment research in the global system to take care of infectious diseases (such as SARS, Ebola, HIV/AIDS, Swine flu, Avian flu etc) that plagued the world in recent times. An infectious disease like COVID-19 and other related pathogenic diseases strike humanity with impunity while the whole 'scientific world' so-called looks hapless. Science and technological nuances has been developed (e.g., modern computers and accessories, mobile phones, aircrafts, vehicles fitted with modern communication gadgets, modern military accruements etc) by states and world political leadership to reap the economic benefits therein, to the detriment of health issues to police the global world. Issues of realpolitik is ingrained or pre-occupied the minds of developed and developing states over global health. Spread of COVID-19 
and its effects has made nonsense of the trillions of dollars states accumulated prior to the outbreak of the disease. This means, globalization and its benefits in terms of capital accumulation are made 'useless' when global citizens are plagued with a pathogenic disease like the novel coronavirus without a clear-cut remedy or antidote.. The absence or the inability of the scientific world to develop a vaccine and other medications (owing to lack of priority, paltry investments, years of neglect or combination of these by governments across the globe) to combat the devastating effects of COVID-19 is a monumental failure of the global world.

Again, COVID-19 has spread to the nook and cranny of the globe like forest wildfire due to as there was paucity of information about the disease at the outset. This was due to local exigencies and states deliberately shrouding information about the disease in mystery. Precise and adequate information in lieu of the virus was not forthcoming to enable the rest of the world to take pre-emptive precautionary measures to combat the disease. Apart from China 'hoarding' the disease from the World Health Organization (W.H.O) for some months, other states that recorded the disease in their countries either consciously or unconsciously, failed to notify other states about the nature of the pathogenic disease. It is understood that whenever there is a pandemic, states are customarily, thinking inside the box with the sole aim to protect their citizens. They seemed unconcerned about what happens in other states. As stated earlier, the history of infectious diseases and the resulting ramifications are enough to remind political leadership around the world that, no one state can effectively combat an infectious disease of global concern without the combine or joint efforts and coordination of other states in the field of science, resources and well-grilled containment strategies. The failure to recognise this basic principle in the fight against COVID-19, facilitated the stagnation of the global economy with its resulting and devastating consequences on humanity and global security.

Third, the misconception at the outset by world leaders that the COVID-19 was 'Chinese-virus' further fuelled the unprecedented spread of the virus. To the surprise of world leaders, in less than six (6) months, the so called 'Chinesevirus', leapfrogged Chinese borders, metamorphosed and 'christened' as global-virus accompanied with catastrophic deaths, fear and panic, disruption of world economies, outrageous unemployment levels, stark poverty, lockdowns or curfews and other draconian policies with its resulting discomforts to humanity. Many countries downplayed the efficacy of COVID-19 to destabilize their 'robust' economies. For instance, President Trump was caught up in taking a decisive decision between science and economics. He chose the latter as he was more eager to re-open the American economy to enable Americans return to work before 2019 Easter. Certainly, Trump was much concerned with the American political economy resuscitation than protecting the lives of citizens at risks - especially in New York, New Jersey, Chicago, Massachusetts, California and Virginia among others. In other cases, world leaders made pronouncements that made citizens to defy established protocols by the World Health Organization (W.H.O). For instance, in Brazil and the USA, the presidents made pronouncements that emboldened citizens to defy lockdown orders imposed on them by governors and other local authorities. Due to such pronouncements some citizens congregated in various places to register their protest against COVID-19 protocols advocated by the WHO and Centre for Disease Control (CDC). It was not surprising that the USA and Brazil whose presidents downplayed the catastrophic nature of the virus, soon became the epicentres of COVID-19 pandemic with surging and alarming proportions of the rates of daily infectious and morbidity.

Besides, the spread of coronavirus pandemic with the speed demon around the world, was influenced by the panic evacuations of nationals from the epicentre - Wuhan, in the Hubei Province. America and many European states who evacuated their nationals at the peak of COVID-19 in Wuhan, China, invariably imported or raked in the disease into their states. It is therefore not surprising, the Americas and the European states assumed the epicentre of the disease that claimed many lives than China. Africa was not left out in the evacuation milieu with Egypt, Morocco, South Africa, Algeria, Nigeria and Ghana having more infectious cases. These countries joined the USA and some European states to evacuate nationals from China - except Nigeria and Ghana at the peak of the evacuations. Also, the delayed in contact tracing and testing of evacuees from the epicentre fuelled spread of COVID-19 around the world. They interacted with family, close associates and the generality of society. The evacuees' though asymptomatic of the disease, became the carriers of the 'virus' and transmitted the infectious disease from one person to another either consciously or unconsciously. Several states have suddenly woke up from their slumber and are now engaged in contact tracing and testing at a time when lots of people have already succumbed to the infectious disease.

Furthermore, the spread of COVID-19 and the recorded catastrophic deaths it has claimed so far around the world are as a result of the dysfunctional and disarticulation between global capital accumulations expressed in Gross Domestic Product (GDP) of states, and global investment in the health sector. COVID-19 has exposed the poor investments in the health sector in both developed and developing states. States and International Financial Institutions (IFIs) are constantly and unrepentantly ingrained in economic and security issues such as World Trade, Stock Markets, manufacturing and export of commodities' nuances, crude oil pricing, and stockpile of arms, terrorism combat, border security, influx of illegal immigrants, surveillance on export and import of narcotic drugs and the struggle for global dominance. While the pursuit of economic and security interest of states are plausible in the international system, investment in the health sector has not been given the needed priority than earlier thought by global actors. This partly explains why United States of America (U.S.A), Italy, Spain, France, Great Britain 
and other petit states, have their health facilities struggling to devise containment strategies as the devastating effects (e.g. human life, global economy and security) of coronavirus pandemic on citizens continue unabated. Health facilities in America and several other European states are found to be 'poorly' equipped to manage COVID-19 pandemic pandemonium. Basic facilities like ventilators and Personal Protective Equipment (PPEs) like nose masks, surgical gloves and hand sanitizers among others, were either lacking in some health facilities or inadequate in another to contain and treat infected cases. Hence, many medics were inadvertently or unwittingly infected themselves with the virus (e.g., Italy, Spain, United Kingdom, US, Germany, Iran etc) while in line of duty to save their compatriots. The medics so infected (even though asymptomatic at the initial stages but infectious to other persons) had contact with their family, friends and non-COVID-19 patients under their care. These exigencies undoubtedly contributed to fuelling spread of the virus disproportionately. The scenario of inadequate medical logistics - especially ventilators - was pervasive in Italy, Spain, France and the U.S.A. Thus, empowering health professionals with the painful discretion to choose between who should have access to a ventilator in order to survive, and who should die.

Finally, the clash of science and politics also accelerated the infection and spread of COVID-19 cases across the world. The etiologic of epidemiology of science in the last couple of years, have failed in predicting possible emerging trend of pathogenic diseases. This has been counterbalanced by broader social, political, economic, cultural and technological changes [14]. The outbreak of COVID-19 coincide with 2020 election of some sovereign states including the U.S.A and Ghana for example. The quest to retain executive or federal power is forcing some political leaders to downplay the threat of COVID-19 (e.g. Presidents of United States, Brazil, Belarus and Nicaragua spread scepticism) by taking certain decision (s) which are at variance with scientific knowledge on pathogenic diseases (e.g. COVID-19) to score political points, increase legitimacy of their governments or restore the economic shambles before election due date. It is altruistic that many electors approach the voting booth with bread and butter issues in mind. Since the outbreak of COVID-19, businesses have either closed down due to the scare, fear and panic of the coronavirus or under lockdown orders in their respective states. Consequently, millions of people across the world have lost their economic livelihoods that threatens survival, food, rent charges and the general well-being of families. Rational electors are guided by their personal and family circumstances in the determination of the choice of candidate while at the voting booth to cast their vote. Hence, political leaders are eager to re-open lockdown economies in spite of the risks associated with it. The sudden ease of restrictions and lockdowns are but, efforts by political leadership to resuscitate stagnated and struggling economies in order to bolster the legitimacy of governments as well as increase the chances of their re-election bid.

\section{Effects of COVID-19 and Global Security}

The COVID-19 is arguably the worst global pathogenic pandemic in decades. Its impact on global economies and security cannot be underestimated. The pandemic has had profound effects on global security. There are many economic issues that have security implications. Some of such economic issues include job losses, stark poverty, and hunger, individuals' inability to pay rents and bills, and the inability of states to provide welfare services to the vulnerable in society. All these have global security implications. COVID-19 impacted negatively on global economy and security. This study summarized effects of coronavirus on global security into a four-fold schema.

The positive performance indicator of the global economy has been the linchpin purveyor to global peace and security. However, the spread of coronavirus across states, and the resulting inability of businesses to continue production, exchange of goods and services have rendered many developed and developing states practically impotent to manage the soaring job losses. Stark poverty and the evergrowing unemployment levels are conduits for states instability. The impact that the global economy has on the stability of individual states is enormous [15]. COVID-19 virtually halted global trading or economic activities manufacturing, trade, aviation, shipping, hospitality, productivity, labour etc- with global security implications for states that rely heavily on other states for essential goods and services. Hence, the panic reactions or responses from global political leadership is to reverse the status quo (unemployment surge, poverty and security issues etc), while fighting COVID-19 at the same time. These two scenarios restoring economic life of a state and pandemic combat have influenced the roll out of unplanned stimulus packages in trillions of US dollars around the world to support businesses and the vulnerable in society. The value of these packages have since eroded or turned paltry as the figures for unemployment, poverty and starvation surges at an exponential rate. The core foundation of many states are already wobbling as citizens can no longer bear the brand of lockdowns in hunger and poverty in most developing states. In South Africa, Kenya, Nigeria, Ghana, Uganda and India for example, citizens have converged and scrambled to receive food supplies from their governments. The inadequate supply of food to the vulnerable in society by the state, and the lack of employment opportunities for the teeming workforce who have lost their jobs due to COVID19 pandemic are already causing social unrest around the world. These unrest have the potential to ravel global security if global actors fail to halt the spread of the virus.

Closely related to above is the loss of both skilled (e.g., health professionals, military and police officers, engineers, pilots, architects etc) and unskilled (e.g., farm, construction, factory hands, sales, laborers etc) labor to COVID-19. Globally, the number of infected cases of COVID-19 increases astronomically on daily basis as death toll continue 
to surge across states. The number of infected case count worldwide is 22.4 million from 214 countries and territories, while the death toll stood at 788,000 as at August 20, 2020 [16]. For example, there is an increased surge of infected cases among health professionals and national security forces. Developed and developing countries risked the health needs of police and the military using the institutions as frontline workers besides health professionals to offer humanitarian services and also, to enforce lockdown orders and other COVID-19 protocols. This has exposed the security services to coronavirus pandemic. Hence, several security personnel were/are infected - there is obfuscation on the number of security forces who succumbed to the virus and those infected - with the COVID-19 virus in the line of duty. The security personnel were infected with the virus at the period where wearing of nose masks was either not recommended or its use was discouraged by the World Health Organization (W.H.O). There is no gainsaying that a weakened national security apparatuses prefaced by a pandemic are a serious threat to the workings of the international system - global security. Terrorist groups are likely to take advantage of weakened national security forces around the world by launching lethal attacks on populations if the infection rate of the virus among security and health professionals are not eliminated or minimized.

The current pandemic (i.e., COVID-19), has resulted in global food supply chain fluff or crisis including volatile food price surge around the globe. National food banks are struggling to keep pace with the increasing demands for food worldwide. Food security is situated within the complex sociolegal, economic, political, geographic and cultural context [17]. Hence,

... it is difficult, if not impossible to detach the role of food security from themes such as trade, agricultural reforms, rural, economic development, and global security (p. 1).

Food security is inextricably linked to the complex web of human existence. Food insecurity or the lack of it, has often led to violent uprisings in states. COVID-19 lockdown orders by governments and subsequent rationing of food to the vulnerable in society around the world ended in violent scamper in some states such as South Africa, Kenya, Nigeria, Ghana, Togo, Zimbabwe and protests against lockdown orders in the United States, Israel, Brazil, France, India, Iran, and the United Kingdom among others. Food is a major determinant to the survival of the human taxonomy. Shortage of food in the global system is a security threat to state's stability. COVID-19 pandemic has paralysed farming activity worldwide. Post-COVID epoch may pose more serious food security challenges than it is now to states and humanity in general. Globally, states are working assiduously to halt the virus from further spread and threat to humanity while battling food insufficiency, hunger and poverty at the same time. The disease has thus far defied all global interventions aimed at its recession - there is increase worse spikes of the disease in the Western world and Europe.

There is a symbiotic relationship between health and security at the national and global levels. The security services sector is mandated to enforce law and defend the country's borders by land, sea and air. In a pandemic of the magnitude of COVID-19, service members had to walk on a tightrope to balance public safety and public health. The spread and the debilitating effects of COVID-19 necessitated the deployment of police, military and other security apparatuses across states to assist in humanitarian as well as enforce lockdown directives. In the process, many of these personnel are reportedly infected with the disease, while a few other service men and women have already succumbed to the coronavirus pandemic. In the United States for example, a little over 4,000 service members have been tested positive for COVID-19 since March, 2020. Many others are reportedly sick and unable to render service to community and country. It is unclear if the death toll of service members are added to the national statistics or data in the USA. Security agencies infected with a virus like COVID-19 has the propensity to wreak havoc inability to perform core mandate of defence and humanitarian services - if stringent measures are not taken to halt its spread between and among security personnel. A weakened military or police force is a threat to state security and global stability. Terrorist groups, drug barons' state-sponsored armed groups and rogue states will take advantage of weak service members owing to a pandemic to threaten global security and stability of states worldwide.

\section{Policy Action for the Future}

Interconnectedness of nation-states, imply 'free' travels or movements of people around the globe. As the world has modernized, urbanized, and globalized, the range of threats to human health has equally multiplied in several folds [18. 2]. Accordingly, the emergence of COVID-19 calls for a multifaceted shift from the traditional and narrow view of global security. The huge investments in armament and nuclear weapons have been rendered inoperable or useless at a time the whole global system is threatened of human extinction. The modern weaponry are certainly not Bbombers, nuclear weapons, jet fighters, warships, rockets, artillery, missile defense systems, and the mind-boggling arms race in stockpiling lethal ammunition in space. As succinctly captured,

Clearly... traditional state arsenals of military force, nuclear deterrents, or clandestine intelligence capabilities will offer little protection against an "invasion" of lethal microbes ([19], p. 1).

COVID-19 pandemic urgently calls for a shift in orientation to better safeguard humanity and ensure global security. The novel coronavirus is killing hundreds of thousands of people around the world. Besides the death toll, the curfews imposed (i.e., the stay-at-home orders), freeze on economic activity and subsequent job losses are enough global security threats to chart a new course in order to prevent a reoccurrence of a pandemic scourge reminiscent of COVID-19. The course of action that this paper proffers is engrafted in a three-fold schema. First, the overwhelming healthcare system around the world is the major reason for 
the uncontrollable spread of the novel coronavirus pandemic. States need to marshal all available resources to invest in healthcare system in both domestic and abroad. Investing in healthcare abroad may superficially, seem absurd to some political leaders around the globe - especially, political leaders whose policies are but, inward-looking and 'myopic' view of the world system. There is incomputable benefit states are likely to derive if collective investments are strategically made abroad to prevent infectious diseases from diffusion from one geographical area to the rest of the world. States will be spared of the unbudgeted stimulus package epidemics; stagnated business activity, demands of unemployment benefits, weird social or physical distancing, closure of educational institutions and the catastrophic death toll among others. Second, pandemics and epidemics worldwide must be considered as a potential threat to global security by global actors - irrespective of the provenance of a virus or disease. Accordingly, states should assist by sending epidemiologists and other healthcare professionals abroad to deal with an emerging epidemic outbreak or an infectious disease. COVID-19 pandemic has established beyond reasonable doubt that, the scamper or hasty evacuation of nationals from the epicentre was flawed and miscalculated to say the least. Finally, the purveyors of global politics should consider an institutionalization or a setup of global fund purposely, to halt spread of epidemic of pandemics everywhere across the world. States in the world system are to make annual contribution into the fund to be managed by the United Nations Organization (U.N.O) or one of its affiliates. In this perspective, states - whether thrifty or 'wasteful' in spending national resources - financial burden may lessen whenever there is a future global pandemic.

\section{Conclusion}

The world is characterized with epidemic of pandemics that recur in almost every year. Pandemic outbreaks are a threat to national and global security. These global pandemics causes disruption in the economic activity of countries, devastating shocks to national populations, fear and panic, global economy and supply chain management, and the general security needs of society. COVID-19 brought surreal feeling worldwide. It is an undeniable fact that, coronavirus is the worse pandemic in the history of infectious diseases that negatively impacted the world in decades. The disease may not equal the catastrophic death toll of HIV/AIDS, Spanish flu, Ebola, SARS, MERS, Black Death, Tuberculosis and malaria for instance. Yet, the pandemic has immense consequence on the economy of states, job losses of individuals, families, businesses, sports and global security in general. The promises of securing a possible vaccine across the globe have largely remained pipe dreams. Never in the twilight of history of pathogenic diseases, has the world suffered disproportionally in terms of halting of global trading activities, manufacturing, hospitality, and aviation industries like COVID-19 pandemic. COVID-19 need a global response and not a blame game, scapegoating or propaganda to quench its wrecking and wracking infection capability. World leaders are better off coordinating the intellectual, scientific, financial and openness worldwide to halt the devastating spread of the virus. The state-centric approach to halt the spread of the virus have thus failed to glitter, while national populations continue to shrivel and die. Probably, the only positive outcome of the COVID-19 pandemic management botch of world leaders is that, the human taxonomy continue to endure.

\section{Competing Interest}

The author do not have any possible conflict of interest.

\section{References}

[1] Coronavirus, (2012). Encyclopaedia Britannica. Chicago: Encyclopaedia Britannica Ultimate Reference Suite.

[2] Huang, Y. (2015). Pandemics and security, in Rushton, Simon \& Jereme, Youde (Eds.). Routledge handbook of global health security. Routledge, Taylor \& Francis Group.

[3] Mclnnes, C. \& Lee, K. (2006). Health and foreign policy. Review of International Studies, Vol. 32, No. 1, pp 5-23.

[4] Spievogel, J. J. (2000). Western civilization, $4^{\text {th }}$ ed. Cengage Learning College.

[5] Mckay, J. R., McLellan, A. T. \& Alterman, A. L. (1992). An evaluation of the Cleveland criteria for impatient treatment of substance abuse. American Journal of Psychiatry, 149, 12121218.

[6] Johnson, N. P. A. C. \& Mueller, J. (2002). Updating the accounts: Global mortality of the 1918 - 1920 Spanish Influenza Pandemic. Bulleting of the History of Medicine, Vol, 76, No. 1, pp 105-115.

[7] Bouskill, K. E. \& Smith, E. (2019). Global health and security Threats and opportunities. Rand Corporation. https//www.jstor.com/stable/resrepi19904.

[8] Milner, H. V. (1998). Rationalizing politics: The emerging synthesis among international politics and American and comparative politics. International Organization. Vol, 32, No 4, pp 759-786.

[9] Brown, C. \& Ainley, K. (2005). Understanding International relations, $3^{\text {rd }}$ ed. Palgrave Macmillan.

[10] Waltz, K. (1990). Realist thought and neorealist theory. Journal of International Affairs. (44), pp 21-37.

[11] W.H.O. (2004h). Report: Consultation on the revision of the International Health Regulations in the Western Pacific Region. Retrieved: www.who.int/ihr/revisionprocess/wpro.2004_09_10.pdf?ua=1.

[12] Elbe, S. (2010). Haggling over viruses. The downside risks of securitizing infectious disease. Health Policy and Planning; 25. 476-485.

[13] Kapur, K. \& Suri, S. (2020). Public health is a question of national security, in Report Title: Challenges of global governance amid the COVID-19 pandemic. Council on Foreign Relations. https://wwwjstor,org/stable/resrep24934.13. 
[14] Davies, S. E. Kamradt-Scott, A. \& Rushton, S. (2015). Disease diplomacy: International norms and global health security. Johns Hopkins University Press.

[15] Al-Rodhan, N. R. F. \& Kuepter, S. (2007). Stability of states: The nexus between transnational threats, globalization, and internal resilience. Slatkine.

[16] Petterson, H., Manley, B. \& Hernandez, S. (2020). Tracking coronavirus' global spread. Cable News Network World. Accessed: http://www.cnnworldnews.
[17] Schanbacher, W. D. (2010). The politics of food: The global conflict between food security and food sovereignty. Praeger Security International.

[18] Elbe, S. (2018). Pandemics, pills and politics: Governing global health security. Johns Hopkins University Press.

[19] Elbe, S. \& Buckman-Merret, G. (2017). Data, disease and diplomacy: GISAID'S innovative contribution to global heath. Global Challenges 1: 33-46. 